\section{Severe congenital non-autoimmune hyperthyroidism associated to a mutation in the extracellular domain of thyrotropin receptor gene}

\author{
Hipertireoidismo congênito não autoimune \\ grave associado com uma mutação no domínio \\ extracelular do gene receptor da tirotrofina
}

Paula A. Scaglia', Ana Chiesa², Gabriela Bastida3 , Mirta Pacin ${ }^{3}$, Horacio M. Domené', Laura Gruñeiro-Papendieck ${ }^{2}$

\section{SUMMARY}

Activating mutations in the TSH Receptor (TSHR) gene have been identified as the molecular basis for congenital non-autoimmune hyperthyroidism. We describe the clinical findings and molecular characterization in a girl who presented severe non-autoimmune hyperthyroidism since birth, born to a mother with autoimmune thyroid disease. She was treated with methylmercaptoimidazol and $\beta$-blockers, but remained hyperthyroid and required total thyroidectomy. To characterize the presence of an activating mutation, the whole coding sequence and intron-exon boundaries of TSHR gene were analyzed. The patient was heterozygous for p.Ser281Asn mutation and p.Asp727Glu polymorphism. This recurrent mutation, p.Ser281Asn, characterized in vitro by increased basal production of cAMP, is the unique germline activating gene variant described so far in the extracellular domain of TSH receptor. Interestingly, the patient's mother presented hyperthyroidism but without any TSHR gene activating mutation. Although congenital non-autoimmune hyperthyroidism is a rare condition, it should be investigated when severe disease persists, even in a newborn from an autoimmune hyperthyroid mother, in order to differentiate it from the more common congenital autoimmune disease. Arq Bras Endocrinol Metab. 2012;56(8):513-8

\section{SUMÁRIO}

Mutações ativadoras no gene receptor de TSH (TSHR) foram identificadas como a base molecular do hipertireoidismo congênito não autoimune. Descrevemos os achados clínicos e a caracterização molecular de uma menina que apresentou hipertireoidismo autoimune grave desde o nascimento, nascida de uma mãe com desordem tiroidiana autoimune. Tratada com metilmercaptoimidazol e $\beta$-bloqueadores, ela permaneceu com hipertiroidismo e necessitou de tiroidectomia total. A fim de caracterizar a presença da mutação ativadora, foram analisados toda a sequência codificadora assim como os extremos dos íntrons e éxons do gene TSHR. A paciente era heterozigota para a mutação p.Ser281Asn e para o polimorfismo p.Asp727Glu. Essa mutação recorrente, p.Ser281Asn, caracterizada in vitro pelo aumento da produção basal de cAMP, é a única variante genética ativadora da linhagem germinativa descrita até hoje no domínio extracelular do receptor de TSH. Interessantemente, a mãe da paciente apresentou hipertireoidismo sem qualquer mutação ativadora do gene TSHR. Embora o hipertireoidismo congênito não autoimune seja uma condição rara, ele deve ser investigado quando há persistência da doença grave, mesmo em um recém-nascido de uma mãe com hipertireoidismo autoimune, a fim de se diferenciar o caso da forma mais comum da doença autoimune congênita. Arq Bras Endocrinol Metab. 2012;56(8):513-8
${ }^{1}$ Centro de Investigaciones Endocrinológicas (CEDIE, CONICET), Buenos Aires, Argentina ${ }^{2}$ Hospital de Niños "Ricardo Gutiérrez", Endocrinology Division, Buenos Aires, Argentina ${ }^{3}$ Hospital "E. Castro Rendon", Pediatrics, Neuquén, Argentina

Correspondence to: Paula A. Scaglia Centro de Investigaciones Endocrinológicas (CEDIE, CONICET) Hospital de Niños "Ricardo Gutiérrez", Gallo 1330 C1425EFD - Ciudad Autónoma de Buenos Aires, Argentina pscaglia@cedie.org.ar

Received on July/12/2012 Accepted on Sept/12/2012 


\section{INTRODUCTION}

$\mathrm{N}_{\mathrm{in}}^{\mathrm{c}}$ eonatal hyperthyroidism is a rare disease affecting about one out of 50,000 neonates (1). It is usually caused by transplacental passage of thyrotropin receptor stimulating antibodies (TRAb) in women with history of Graves' disease or, more rarely, Hashimoto thyroiditis (2). The neonatal disease is observed within the first days of life, requiring immediate treatment because of its high morbimortality. Although severe, this condition is usually transient, with spontaneous resolution when maternal antibodies are cleared from the neonate's circulation, within the first four months of life $(3,4)$.

More recently, an even more uncommon type of neonatal hyperthyroidism has been described, resulting from activating mutations of the TSH receptor (TSHR) gene and causing constitutive activation of the intracellular signaling cascade (5-9). Neonates with this uncommon disorder share the same clinical manifestations of severe neonatal thyrotoxicosis, but with more prolonged symptoms of hyperthyroidism.

The mutations in the TSHR gene leading to nonautoimmune hyperthyroidism (NAH) may be inherited in an autosomal dominant manner (familial or hereditary, HNAH), or may occur sporadically as a de novo condition (SNAH). To date, at least 20 different mutations have been identified as the cause of HNAH in 27 families with more than a hundred affected individuals, while only 15 subjects with 10 different mutations leading to SNAH have been described $(10,11)$.

We report the clinical findings and molecular characterization of a girl who presented a persistent and severe congenital hyperthyroidism due to an activating mutation of the TSHR gene, born to a mother with autoimmune thyroid disease.

\section{CASE REPORT}

The study was conducted in accordance with the Helsinki Declaration (12). Written informed consent for molecular studies was obtained from the mother. The study was approved by the "E. Castro Rendon" Hospital ethics committee.

The girl is the only daughter of a 31-year-old mother, born at 38 weeks of gestational age after a poorly controlled pregnancy, with no evaluation of thyroid function. She was delivered by cesarean section because of fetal tachycardia and suffering. Her APGAR score was $6 / 8$ and she required monitoring in an Intensive Care Unit. Her birth weight was $2410 \mathrm{~g}$ (-1.7 SDS); birth length, $47 \mathrm{~cm}(-0.87 \mathrm{SDS})$; and head circumference, $33.3 \mathrm{~cm}\left(<3^{\text {rd }}\right.$ percentile $)$. Tachycardia $(220$ beats/min) was present at birth, and thyroid profile confirmed hyperthyroidism (Table 1).

At 8 days of life she had persistent tachycardia (160-200 beats/min), easy sweating, irritability, and an altered thyroid profile (Table 1). Thyroid gland ultrasound showed a normal sized eutopic gland. Bone age, assessed by hand and wrist maturation (13), was advanced by 1 year.

With diagnosis of hyperthyroidism, she began treatment with methylmercaptoimidazol (MMI) and cardiac $\beta$-blockers. Nevertheless, she persisted hyperthyroid with relapses, after an attempt to reduce the MMI dose. Her follow-up showed weight always below the $3^{\text {rd }}$ percentile, normal height around the $50^{\text {th }}$ percentile, while bone age, advanced during the first 3 years, approached chronological age at the age of 4 .

At 6.9 years of age, she underwent a total thyroidectomy (Table 1). Histological examination revealed follicular cell hyperplasia, with no signs of either malignancy or lymphocytic infiltration (Figure 1). After surgery, hypothyroidism was confirmed and LT4 treatment was indicated $(2.5 \mu \mathrm{g} / \mathrm{kg}$.day). The neuropsychological outcome was normal, without craniosynostosis.

Hyperthyroidism had been diagnosed in her mother at 14 years of age, when she presented goiter and high ${ }^{131}$ I uptake (64\% at $24 \mathrm{~h}$ ) (Table 2$)$. She was initially treated with MMI, but because of poor compliance she received two doses of ${ }^{131}$ I. She remained uncontrolled and without treatment until delivery. With signs of overt hypothyroidism and positive anti-thyroperoxidase antibodies (ATPO), she began thyroid hormone replacement (LT4 $200 \mu \mathrm{g} /$ day) (Table 2). Data from the father were unavailable.

Table 1. Thyroid profile of the patient

\begin{tabular}{lccccc}
\hline & $\begin{array}{c}\text { At 2 } \\
\text { days of } \\
\text { life }\end{array}$ & $\begin{array}{c}\text { At } 8 \\
\text { days of } \\
\text { life }\end{array}$ & $\begin{array}{c}\text { Reference } \\
\text { range }\end{array}$ & $\begin{array}{c}\text { At 6.7 years } \\
\text { (on MMI } \\
\text { treatment) }\end{array}$ & $\begin{array}{c}\text { Reference } \\
\text { range }\end{array}$ \\
\hline $\mathrm{TSH}(\mathrm{m} / \mathrm{U} / \mathrm{L})$ & 0.03 & $<0.01$ & $0.8-10.0$ & $<0.01$ & $0.5-6.5$ \\
$\mathrm{~T} 4(\mathrm{\mu g} / \mathrm{dL})$ & $>24.8$ & $>24.8$ & $6.5-16.3$ & 6.1 & $6.0-14.0$ \\
$\mathrm{~T} 3(\mathrm{ng} / \mathrm{dL})$ & 342 & 422 & $100-300$ & 202 & $80-220$ \\
$\mathrm{FT4}(\mathrm{ng} / \mathrm{dL})$ & & $>7.7$ & $0.9-2.6$ & 0.53 & $0.80-2.20$ \\
ATPO (IU/mL) & $<20$ & $<20$ & $<34$ & & \\
TRAb (\%) & & $<10$ & $<15$ & & \\
\hline
\end{tabular}




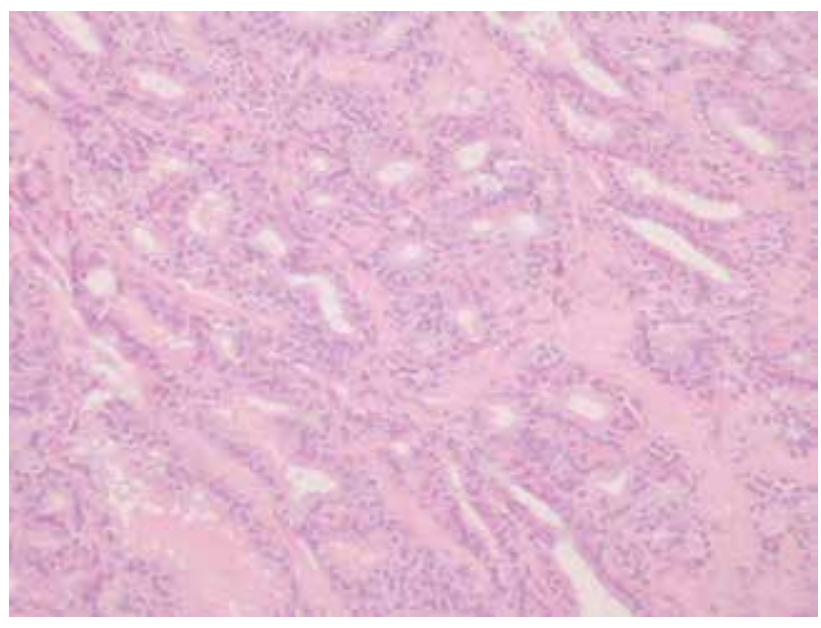

Figure 1. Histological finding in the removed thyroid gland: follicular cell hyperplasia without signs of malignancy or lymphocytic infiltration.

Table 2. Thyroid profile of the patient's mother

\begin{tabular}{lccc}
\hline & 14 years & At delivery & $\begin{array}{c}\text { Reference } \\
\text { range }\end{array}$ \\
\hline TSH (m/U/L) & & 8.0 & $0.5-5.0$ \\
T4 ( $\mu$ g/dL) & 17.0 & 4.4 & $4.5-12.5$ \\
T3 (ng/dL) & 670 & 66 & $80-220$ \\
FT4 (ng/dL) & & 0.36 & $0.80-2.20$ \\
ATPO (IU/mL) & & 58 & $<34$ \\
ATG (IU/mL) & & 24.5 & $<115$ \\
TRAb (\%) & $<10$ & $<15$ \\
\hline
\end{tabular}

Genomic DNA from the patient and her mother was extracted from peripheral blood based on the use of cetyltrimethylammonium bromide (CTAB) lysis buffer and isoamyl alcohol-chloroform extraction (14). The whole coding sequence (exons 1 to 10 ) and intron-exon boundaries corresponding to TSHR gene (GeneID: 7253; Genebank: NG_009206.1, NM_000369.2, NP_000360.2) were amplified by PCR using genomic DNA both from the patient and her mother as template, and automatically sequenced with Applied Biosystems 3730xl DNA analyzer (Macrogen Inc. Seoul, Korea) with specific oligonucleotide primers (PCR protocols and primers sequences are available upon request).

Serum levels of TSH, T4, T3, and ATPO were measured by immunometric chemiluminescent assay (ICMA, Immulite 2000, Siemens Healthcare Diagnostics, USA), and Thyroid Receptor antibodies (TRAb) by radioimmunoassay (RIA, RSR, Cardiff, UK).

\section{RESULTS}

Sequencing of TSHR gene in the patient revealed a heterozygous $\mathrm{G}$ to A transition in exon 9 (rsl21908878, c. $842 \mathrm{G}>\mathrm{A}$ ), predicted to result in a missense mutation changing serine 281 to asparagine, (p.Ser281Asn, p.S281N) in the extracellular domain of TSH receptor. Also, a heterozygous $\mathrm{C}$ to $\mathrm{G}$ transversion was found in codon 727 (rs1991517, c.2181C>G, exon 10), resulting in the substitution of aspartic acid by glutamic acid, a known single nucleotide polymorphism (SNP) (p.Asp727Glu, p.D727E) (Figure 2).

In the mother, no genetic variants were detected in codons 281 or 727 of the TSHR gene, and she was homozygous for the wild type allele in both positions. However, we found a heterozygous $\mathrm{G}>\mathrm{A}$ transition in codon 459 (rs113951800, c.1377G>A, exon 10), predicted to result in a silent polymorphism (p.Ala459Ala), not present in her daughter's sample.

\section{DISCUSSION}

The SNAH phenotype was first described by Kopp and cols. in a patient with the p.Phe631Leu mutation in the TSHR gene (6). Most of the patients with SNAH reported to date (10 out of 14), were born prematurely and, when compared to $\mathrm{HNAH}$, presented earlier and more severe symptoms in the neonatal period $(10,11)$. Our patient was born at term with normal size, and was severely hyperthyroid since birth, with tachycardia and fetal suffering.

Although congenital NAH is a rare condition, differential diagnosis with autoimmune disease should be carried out when severe neonatal disease persists, even when the mother presents autoimmune hyperthyroidism, in order to differentiate it from the more common congenital autoimmune disorder. In contrast to patients with neonatal Graves' disease, patients with severe and persistent non-autoimmune hyperthyroidism should be treated more aggressively, requiring either total thyroidectomy or radiation to control the disease.

Reported thyroid size is variable in patients with SNAH, with diffuse neonatal goiter observed in 9 out of 14 described patients. Our patient had a normal sized eutopic gland.

Regarding clinical features in NAH, hyperthyroidism persists and commonly relapses following withdrawal of antithyroid drugs, and even after subtotal thyroidectomy. In the present case, the patient had multiple relapses 

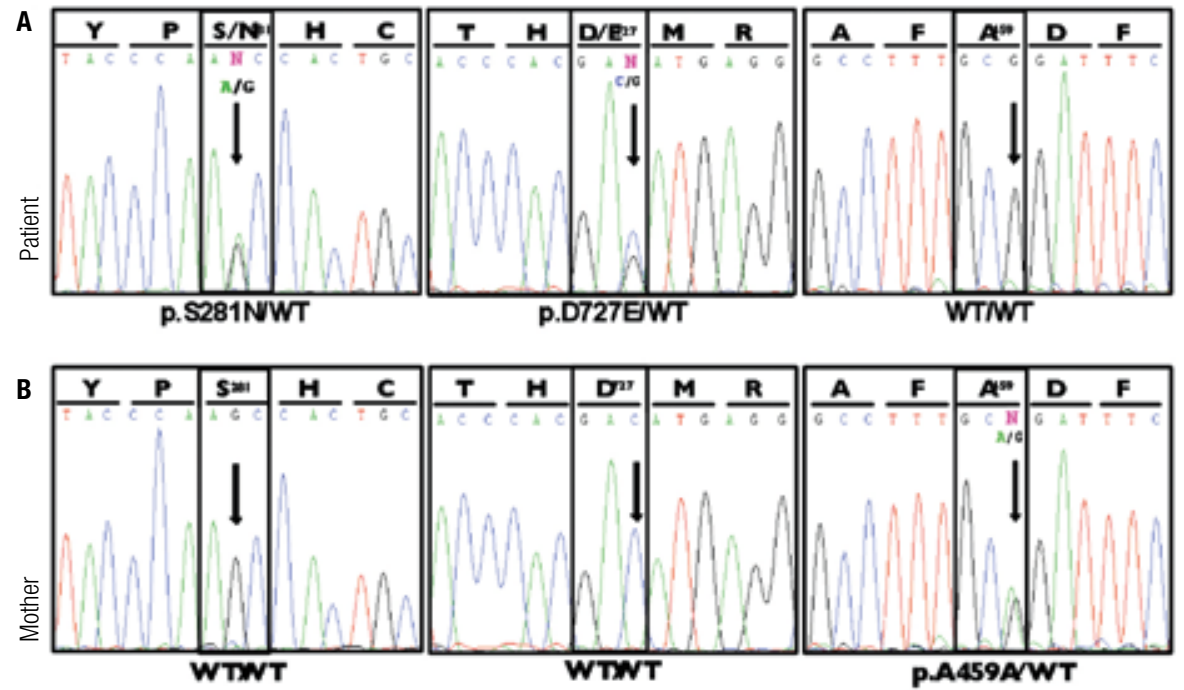

Figure 2. Electropherograms showing partial sequencing results of TSH receptor (TSHR) gene from the patient (A) and her mother (B).

Patient's genomic DNA sequencing shows a heterozygous $G$ to $A$ transition at the $2^{\text {nd }}$ base of codon 281 (exon 9) leading to p.Ser281Asn substitution (A, left panel), and a heterozygous transversion $C$ to $G$ in codon 727 (exon 10), resulting in p.Asp727Glu substitution (A, middle panel), while her mother is homozygous for the wild type (WT) allele in both codons (B, left and middle panels). The right panel of Figure B displays a heterozygous $A$ to $G$ transition in the $3^{\text {rd }}$ base of codon 459 (exon 10), presumably resulting in a silent polymorphism (p.Ala459Ala).

when withdrawal was attempted, persisting hyperthyroid until almost 7 years of age, when thyroidectomy was performed. Antithyroid drugs were administered in all previously reported cases without good response, and radioiodine therapy was indicated in 6 cases, but near total thyroidectomy seems to be the treatment of choice for these patients $(10,15-17)$. Various consequences of prolonged neonatal hyperthyroidism, including multinodular goiter, microcephaly, craniosynostosis, psychomotor disturbances, mental retardation, intrauterine growth retardation, prematurity and low birth weight, have been reported in the literature, but none of these complications developed in our patient.

In this patient, we identified the p.Ser281Asn mutation in the TSHR gene, as well as the p.Asp727Glu polymorphism. Her mother, who harbors the p.Ala459Ala polymorphism, but not the p.Ser281Asn mutation, was hyperthyroid since adolescence without TRAb antibodies, but with low titers of ATPO antibodies, indicating an autoimmune thyroid disorder. Although the father could not be studied, no history suggesting hyperthyroidism was reported. Thus, we might suggest that this is a case of SNAH, resulting from a de novo mutation.

In the patient reported by Grüters and cols. (9), together with the p.Ser281Asn mutation, the authors found the p.Arg528His gene variant, a polymorphism that failed to increase cAMP production in functional studies. Some paternal relatives of the affected child, who presented the p.Arg528His polymorphism but did not harbor the p.Ser281Asn mutation, developed hyperthyroidism with negative TRAb but low positive titers of ATPO antibodies. A similar situation is seen in the present case, as the mother, who is negative for the mutation, presented hyperthyroidism with positive ATPO and negative TRAb.

As observed in other conditions caused by gain-offunction mutations, all patients with congenital NAH reported to date (including the present case) have only one affected allele, and are heterozygous for the germline mutation.

The p.Ser281Asn TSHR gene variant found in this patient has already been described as germline mutation in 3 patients with SNAH $(9,18,19)$, and as somatic mutation in autonomous thyroid nodules $(20)$. In vitro experiments have demonstrated that the resulting mutant TSH receptor displays significantly higher constitutive activity when compared with the wild type receptor, with higher basal production of cAMP $(17,18)$. Interestingly, p.Ser281Asn is the unique germline activating mutation described in the extracellular domain, suggesting that residue 281 is a key position for TSH receptor structure and function. 
Alignment analysis of TSHr, FSHr and LH/CGr amino acid sequences from different animal species reveals that Serine 281 is highly conserved in all three glycoprotein hormone receptors, suggesting that this residue is crucial in maintaining proper three-dimensional structure for receptor function. Serine 281 is located in a highly specific and conserved motif (SHCCAF) within the hinge domain of the receptor, between the extracellular leucine-rich repeat motif and the transmembrane helices $(17,20-22)$. The TSH receptor displays significant constitutive activity, and it has been hypothesized that its extracellular domain in the unbound state would exert a negative constraint maintaining receptor quiescence. Consequently, mutations within the ectodomain would disrupt the three-dimensional structure necessary for receptor silencing, and might lead to increased constitutive activity $(9,17-22)$.

The p.Asp727Glu (p.D727E) polymorphism found in our patient is widely distributed among subjects from different populations. According to the SNP database (dbSNP) of the National Center for Biotechnology Information (NCBI), the minor allele frequency (MAF) is 0.108 for the $\mathrm{G}$ allele (MAF corresponds to 1,000 Genome phase 1 genotype data from 1,094 worldwide individuals, released in the May 2011 dataset). Gabriel and cols. (23) reported higher frequency of p.Asp727Glu in patients with toxic multinodular goiter than in normal controls, and exaggerated cAMP production in response to TSH stimulation when this variant was studied in vitro, suggesting that the variant might play a role in the pathogenesis of thyroid disease in patients with toxic adenoma. However, Mühlberg and cols. (24) were unable to detect any significant differences in p.Asp727Glu gene variant frequency among healthy controls and patients with either NAH or Graves' disease. Similarly, Nogueira and cols. (25) and Sykiotis and cols. (26) also demonstrated, by in vitro expression studies, that the E727 variant receptor was not significantly different from the wild type D727 receptor in terms of basal and stimulated cAMP production. Therefore, it would seem that the p.Asp727Glu variant is unlikely to play a role in the genesis of $\mathrm{NAH}$ or toxic adenoma $(25,26)$.

The heterozygous c. $1377 \mathrm{G}>\mathrm{A}$ transition in exon 10 , present only in the mother, is predicted to result in the silent polymorphism p.Ala459Ala. This variant (rs113951800), included in the NCBI dbSNP with low frequency (MAF: 0.008), has been previously reported in a hyperfunctioning thyroid nodule (23). Even though this is presumably a benign change, in vitro expression and RNA stability studies will be necessary to establish its effect on receptor expression and function, and its potential involvement in thyroid disorders.

Recently, Lueblinghoff and cols. (27) analyzed a possible genotype-phenotype correlation in a systematic review of the SNAH cases reported to date. They could not find any consistent association between the degree of in vitro activity of each TSHR mutant and the clinical course of patients with SNAH, and concluded that this may be due, at least in part, to the restricted number of case reports and limited follow-up. However, the lack of genotype-phenotype correlation in patients with $\mathrm{NAH}$ might also reflect the influence of iodine intake and/or other genetic, epigenetic, or environmental factors.

The molecular characterization of THSR gene mutations in patients with $\mathrm{NAH}$ enables both adequate treatment decision and appropriate genetic counseling. Moreover, recognizing NAH will help to avoid the irreversible consequences of inadequate treatment of this disorder, which probably affects children since their early fetal development.

Acknowledgments: A. Chiesa is a research associate member of the Gobierno de la Ciudad de Buenos Aires. We would like to thank Mrs. Perla Rossano for her technical assistance. This study did not receive any specific grant from any funding agency in the public, commercial or non-profit sector.

Disclosure: no potential conflict of interest relevant to this article was reported.

\section{REFERENCES}

1. Polak M, Legac I, Vuillard E, Guibourdenache J, Castanet M, Luton D. Congenital hyperthyroidism: the fetus as a patient. Horm Res. 2006;65(5):235-42.

2. Becks GP, Burrow GN. Thyroid disease and pregnancy. Med Clin North Am. 1991;75(1):121-50.

3. Ogilvy-Stuart AL. Neonatal thyroid disorders. Arch Dis Child Fetal Neonatal Ed. 2002;87(3):F165-71.

4. Polak M. Hyperthyroidism in early infancy: pathogenesis, clinical features and diagnosis with a focus on neonatal hyperthyroidism. Thyroid. 1998;8(12):1171-7.

5. Duprez L, Parma J, Van Sande J, Allgeier A, Leclère J, Schvartzm $C$, et al. Germline mutations in the thyrotropin receptor gene cause non-autoimmune autosomal dominant hyperthyroidism. Nat Genet. 1994;7(3):396-401.

6. Kopp P, van Sande J, Parma J, Duprez L, Gerber H, Joss E, et al. Brief report: congenital hyperthyroidism caused by a mutation in the thyrotropin-receptor gene. N Engl J Med. 1995;332(3):150-4.

7. de Roux N, Polak M, Couet J, Leger J, Czernichow P, Milgrom E, et al. A neomutation of the thyroid-stimulating hormone receptor in a severe neonatal hyperthyroidism. J Clin Endocrinol Metab. 1996;81(6):2023-6. 
8. Holzapfel HP, Wonerow P, von Petrykowski W, Henschen M, Scherbaum WA, Paschke R. Sporadic congenital hyperthyroidism due to a spontaneous germline mutation in the thyrotropin receptor gene. J Clin Endocrinol Metab. 1997;82(11):3879-84.

9. Grüters A, Schöneberg T, Biebemann $\mathrm{H}$, Krude $\mathrm{H}$, Krohn HP, Dralle $\mathrm{H}$, et al. Severe congenital hyperthyroidism caused by a germline neo mutation in the extracellular portion of the thyrotropin receptor. J Clin Endocrinol Metab. 1998;83(5):1431-6.

10. Gozu HI, Lublingoff J, Bircan R, Paschke R. Genetics and phenomics of inherited and sporadic non-autoimmune hyperthyroidism. Mol Cell Endocrinol. 2010;322(1-2):125-34.

11. Hébrant A, van Staveren WC, Maenhaut C, Dumont JE, Leclère J. Genetic hyperthyroidism: hyperthyroidism due to activating TSHR mutations. Eur J Endocrinol. 2011;164(1):1-9.

12. Helsinki, Finland, June 1964, and amended by the 29th WMA General Assembly, Tokio, Japan, October 1975, 35th WMA General Assembly, Venice, Italy, October 1983, 41st WMA General Assembly, Hong Kong, September 1989, 48th General Assembly, Somerset West, Republic of South Africa, October 1996, 52nd WMA General Assembly, Edinburg, Scotland, October 2000, 53rd WMA General Assembly, Washington 2002 (note of clarification on paragraph 29 added), 55th WMA General Assembly, Tokyo 2004 (note of clarification on paragraph 30 added), 59th WMA General Assembly, Seoul, October 2008.

13. Greulich WW, Pyle SI. Radiographic atlas of skeletal development of the hand and wrist. California: Stanford University Press; 1950.

14. Del Sal G, Monfioletti G, Schneider C. The CTAB-DNA precipitation method a common mini-scale preparation of template DNA from phagemids, phages or plasmids suitable for sequencing. Biotechniques. 1989;7(5):514-20.

15. Esapa CT, Duprez L, Ludgate M, Mustafa MS, Kendall-Taylor $P$, Vassart $G$, et al. A novel thyrotropin receptor mutation in an infant with severe thyrotoxicosis. Thyroid. 1999;9(10):1005-10.

16. Bertalan R, Sallai A, Sólyom J, Lotz G, Szabó I, Kovács B, et al. Hyperthyroidism caused by a gemline activating mutation of the thyrotropin receptor gene: difficulties in diagnosis and therapy. Thyroid. 2010;20(3):327-32.

17. Duprez L, Parma J, Costagliola S, Hermans J, van Sande J, Dumont JE, et al. Constitutive activation of the TSH receptor by spontaneous mutations affecting the $\mathrm{N}$-terminal extracellular domain. FEBS lett. 1997;409(3):469-74.
18. Chester J, Rotenstein D, Ringkananont U, Steuer G, Carlin B, Stewart $L$, et al. Congenital neonatal hypertyroidism caused by germline mutations in the TSH receptor gene. J Pediatr Endocrinol Metab. 2008;21(5):479-86.

19. Biebermann H, Schöneberg $T$, Krude $H$, Gudermann T, Grüters A. Constitutively activating TSH-receptor mutations as a molecular cause of non-autoimmune hyperthyroidism in childhood. Langenbecks Arch Surg. 2000;385(6):390-2.

20. Ho SC, van Sande J, Lefort A, Vassart G, Costagliola S. Effects of mutations involoving the highly conserved S281HCC motif in the extracellular domain of the thyrotropin (TSH) receptor on TSH binding and constitutive activity. Endocrinology. 2001;142(7):2760-7.

21. Jaeschke H, Neumann S, Kleinau G, Mueller S, Claus M, Krause $\mathrm{G}$, et al. An aromatic environment in the vicinity of serine 281 is a structural requirement for thyrotropin receptor function. Endocrinology. 2006;147(4):1753-60.

22. Farid NR, Kascur V, Balazs C. The human thyrotropin receptor is highly mutable: a review of gain-of-function mutations. Eur J Endocrinol. 2000;143(1):25-30.

23. Gabriel EM, Bergert ER, Grant CS, van Heerden JA, Thompson GB, Morris JC. Germline polymorphism of codon 727 of human thyroid-stimulating hormone receptor is associated with toxic multinodular goiter. J Clin Endocrinol Metab. 1999;84(9):3328-35.

24. Mühlberg T, Herrmann K, Joba W, Kirchberger M, Heberling HJ, Heufelder AE. Lack of association of nonautoimmune hyperfunctioning thyroid disorders and a germline polymorphism of codon 727 of the human thyrotropin receptor in a European Caucasian population. J Clin Endocrinol Metab. 2000;85(8):2640-3.

25. Nogueira CR, Kopp P, Arseven OK, Santos CL, Jameson JL, Medeiros-Neto G. Thyrotropin receptor mutations in hyperfunctioning thyroid adenomas from Brazil. Thyroid. 1999;9(11):1063-8.

26. Sykiotis GP, Neumann S, Georgopoulos NA, Sgourou A, Papachatzopoulou A, Markou KB, et al. Functional significance of the thyrotropin receptor germline polymorphism D727E. Biochem Biophys Res Commun. 2003;301(4):1051-6.

27. Lueblinghoff J, Mueller S, Sontheimer J, Paschke R. Lack of consistent association of thyrotropin receptor mutations in vitro activity with the clinical course of patients with sporadic non-autoimmune hyperthyroidism. J Endocrinol Invest. 2010;33(4):228-33. 